\title{
Dental Arts: Discover Prefabricated Bridging
}

\section{RS Carlson}

Inventor of the Carlson Bridge ${ }^{\circ}$, Honolulu, Hawai, USA

Corresponding author: RS Carlson, Inventor of the Carlson Bridge ${ }^{\circledR}$, Honolulu, Hawai, USA.

Received date: March 16, 2020; Accepted date: May 28, 2020; published date: June 15, 2020

Citation: RS Carlson, Dental Arts: Discover Prefabricated Bridging. J Clinical Research and Reports, 4(3); DOI:10.31579/2690-1919/081

Copyright: () 2020 RS Carlson. This is an open access article distributed under the Creative Commons Attribution License, which permits unrestricted use, distribution, and reproduction in any medium, provided the original work is properly cited.

\section{Abstract}

The historically recorded art of dental fixed bridging, prosthetic tooth replacement, first begins with a simple gold wire wrapped about one support tooth to another with a dead tooth in between. By the 1800 s the process evolves to gold "swedged" shell crowns over teeth, without reduction, and a false tooth attached in between. In the early twentieth century, about 1907 as a result of Dr. Tagart's lost wax technique developed, and the electric dental drill, the art of tooth contouring and the cast gold bridge come about.

Keywords: dental arts; prefabricated bridging

\section{Introduction}

The historically recorded art of dental fixed bridging, prosthetic tooth replacement, first begins with a simple gold wire wrapped about one support tooth to another with a dead tooth in between. By the 1800 s the process evolves to gold "swedged" shell crowns over teeth, without reduction, and a false tooth attached in between. In the early twentieth century, about 1907 as a result of Dr. Tagart's lost wax technique developed, and the electric dental drill, the art of tooth contouring and the cast gold bridge come about.

This method of tooth contouring is presented at first as judicious shaving or preparation of the tooth structure and its replacement with cast gold cover, the cast gold restoration. A number of journal articles during this time, however, reported on this process of tooth preparation, often condemning it as "tooth mutilation." In The Dental Cosmos Vol. 61 1921, Dr. Marcus L Ward, a paragon of pedagogy in his time, admonished his colleagues: "I cannot but sound a warning against any practice that necessitates the misguided mutilation of sound teeth."

The porcelain-to-precious-metal-crown known as the "Ceramco" was in its infancy by the early 1970's. Ceramco crowns, PFM, required extensive tooth reduction in the quest of a natural look. Thickness between the metal core and the porcelain was critical in its aesthetic effect.

Today, in the tradition of the Ceramco, the norm is major reduction of all surfaces of the tooth structure preparatory to bridging, about 1.5 to $2 \mathrm{~mm}$, or more. In the $60 \mathrm{~s}$ when "gold was king" gold was used to structure our attachments, crowns, with about 0.5 to $1 \mathrm{~mm}$ reduction, and Steel's Flat Back Facings of porcelain for the pontic facings.

The all-porcelain crown used early in the 1930's until the 1990's, the PJC, fell out of use with the advent of PFM crowns. As of this writing, there are many newer materials available to the profession, allowing for the option to avoid metals altogether. However, tooth reduction persists.
Although fixed bridging has evolved as an art and science it still relies on tooth reduction and potential pulp-dentine complex injury. It is well known that endodontic therapy is on the rise due to these aggressive preparations.

\section{Discussion}

The early 80 s and 90s saw the emergence of light cured composite use (PMMA filled with silica or zirconium) in places heretofore unacceptable in the profession. Minimally invasive dentistry became a byword at that time for many who would avoid tooth preparations deep into dentine as much as possible.

However, the new frontier today is Biomimetic dentistry. Biomimetics is known as "the study of the structure and function of biological systems as models for the design and engineering of materials and machines." For example, composite is composed of: 1) a carbon chain polymer (PMMA) moiety structured much like polymer carbon chains of collagen or the protein rod substance holding enamel rods together (inter rod substance, amelogenin); and, 2) the silica moiety within composite could loosely be analogized to the mineral enamel rods held within the rod substance sheath. Ergo, we have silica within PMMA (composite) as developed by humans. And, enamel rods within amelogenin (human enamel) as developed by Nature.

Dr. Gordon Christianson, well known to Dentistry Today readers, reported his concern regarding pulpal death due to over reduction of teeth in his Clinical Research Associates Newsletter of 1995. ${ }^{(1)}$ At that time he mentioned computer data that demonstrated a close and "significant" correlation of deep crown preparations and resultant need for endodontic therapy. Much research has been done since then on the ill affects and effects of high speed cutting on enamel and dentine. This can be observed in our daily experiences as dental practitioners, if one looks with diligence.

A second alert regarding "killing teeth" surfaced in 2005 in an article "How to Kill A Tooth" that again advused the profession to the dangers of radical misguided tooth reduction. ${ }^{(2)}$ Other authors have also 
voiced their cautionary papers on the subject as did those of the early $20^{\text {th }}$ Century. ${ }^{(6)}$

The systematic and simple replacement of missing teeth without radical manipulation of existing sound structure (tooth mutilation), utilizing scaffolding, or a matrix, of prefabricated material may correctly be characterized as bio-synthetic tissue engineering-
SYNERGY. A whole new conversation about the direction of dentistry for the $21^{\text {st }}$ Century is offered in Stephan C. Bayne's review of the state of the art for restorative biomaterials titled Dental Biomaterials: Where Are We and Where Are We Going.

We present this principle, synergy, as observed in the profession of dentistry, demonstrated in Table 1.

\begin{tabular}{|c|c|c|c|c|}
\hline & Removable flipper & Traditional bridge & Dental Implant & Carlson Bridge $®$ \\
\hline Cost & $\sim \$ 1,740.00$ & $\sim \$ 4,500.00$ & $\sim \$ 6,400.00$ & $\sim \$ 2,100.00$ \\
\hline 1. No. of Visits & $2-3$ & $3-5$ & $12-20$ & 1 \\
\hline 2. Definitive & No & Yes & Yes & Yes \\
\hline 3. Lifespan & $6 \mathrm{mo} .-1 \mathrm{yr}$. & $3-5 y r s$. & $?$ & $3-5 y r s$. \\
\hline 4. Tissue Altered & Little & Yes & Yes & None \\
\hline $\begin{array}{l}\text { 5. Completion } \\
\text { time }\end{array}$ & $1-2$ Weeks & About 1 month & $6 \mathrm{mo} .-1$ year & 1.5 hours \\
\hline 6. Time in chair & 1 hour & $3-6$ hours & $5-15$ hours & $\sim 1.5$ hour \\
\hline 7. Expected pain & No & Moderate to High & Moderate to High & No \\
\hline 8. Needed meds & No & Yes & Yes & No \\
\hline $\begin{array}{l}\text { 9. Easily } \\
\text { modified }\end{array}$ & No & No & No & Yes \\
\hline 10.Alter Shade & No & No & No & Yes-Anytime \\
\hline $\begin{array}{l}\text { 11.LaboratoryCo } \\
\text { st }\end{array}$ & Yes & Yes-High & Yes-Very High & None \\
\hline $\begin{array}{l}\text { 12. Stress } \\
\text { Doctor }\end{array}$ & Very little & Very High & Very High & Little/ Moderate \\
\hline $\begin{array}{l}\text { 13. Galvanic } I \\
(u A)\end{array}$ & (Clasps) -2-3uA & $\begin{array}{l}\text { (Metal) -3- } \\
12 \mathrm{uA}\end{array}$ & (Tit.)-30-200uA ${ }^{1}$ & None \\
\hline $\begin{array}{l}\text { 14. Stress } \\
\text { Patient }\end{array}$ & Little & Moderate/High & Very High & Minimum-None \\
\hline 15. Death Threat & None & Moderate & Moderate /High & None \\
\hline
\end{tabular}

Table 1. Single Tooth Synergetic Replacement Comparison

What Carlson Bridge ${ }^{\circledR}$ Technologies has shown since 1999 is that a fixed dental bridge of very high standards and quality can be done in as little as an hour with restorative dental composites of superior structure, without internal fiber support as proposed by many companies, and a totally new conceptioning.

The art of bridging utilizing minimal tooth reduction had seen very little advancement until denture teeth were first used with fibers and composites. ${ }^{(3)}$ Various clinicians around the early 1990's began to use glass fibers, Kevlar fibers, or other polyethylene fibers as a means of adhering the denture tooth to the natural abutments. Now, most major dental suppliers of dental composites offer their brand of fiber to reinforce tooth attachment in their system false tooth placement.

The use of macro-fiber reinforcement such as this is optional, since its capacity to strengthen the bridge is contentious at best. ${ }^{(3,4,5,6,7,8,9,10)}$ Another common objection to fiber reinforcement methodology is that it is technique sensitive. One must meticulously pay attention to imbedding all fiber portions within the over lying composite and not leaving fiber exposed. We find this method unnecessary, bulky, very time consuming and potentially weakens the bridge rather than strengthening it. Our testing, in concert with with Knight and Whittaker's, reported a 10 to $15 \%$ weakening effect; while van Heumen and Jokstad said the strengthening is equivocal. ${ }^{(10,11)}$ At best no body really knows.
Pure acrylic denture teeth made of PMMA (Poly Methyl Methacrylate) will not bond or polymerize with composites. Their success was dependent on mechanical factors alone and not any chemical bonding factors. The surface interface of the PMMA denture tooth and the composite material used to bond the pontic to the support teeth was the weakest link. Actually there was no link at all since there was nothing to bond to, that is, without silica within the PMMA, there is no covalent bond. We now have PMMA denture teeth that have been said to incorporate nano-hybrid composite, but if that is true, we find that these denture teeth still will not bond to conventional composites either.

There is a very small population of dentists, which is growing in numbers, who are avoiding traditional radical tooth reduction for fixed bridges or who would like to offer an alternative method of tooth replacement for their patients. The art of bridging, or other restorative procedures, for this fraction of bio-dentists is moving in this direction. The recent appearance last year of the Componeer prefabricated laminate system by Coltene-Whaledent witnesses this phenomenon. Other companies are following this innovation of prefab laminates used in the dental office.

\section{WHAT IS THE "WINGED PONTIC" PREFAB BRIDGE?}

Our system of composite tooth replacement began September 1989 and avoided the cumbersome and ineffectual use of fibers. Although macro-fiber reinforcement appears as if it would strengthen attachments and composite itself, much like metal rods in concrete, results vary and 
are equivocal. Again, our studies noted previously found that macrofibers weakened the composite matrix, rather than strengthened it by about $10-15 \%$ as they did in the studies of Knight and Whittaker.

Previous to this innovation, the art of bridging was a slow and methodical lamination of the pontic and then sculpting it as desired. The new Preformed Design Bridging presented as the prefabricated "Winged Pontic" tooth replacement system, employees preformed composite tooth forms that are first adjusted to fit the space of the missing tooth or teeth. Once adjusted to the space, the composite is added to the natural attachment teeth, the appropriate surfaces of the pontic, and gingerly set into the space at the doctor's discretion and preference. The excess material is smoothed onto the abutment teeth and the pontic and then bonded in place. Successive layers of finishing composite are added for strength and aesthetics. Following this phase, the sculpting is employed to craft a custom prefab composite bridge of superior quality.

\section{Case Study}

This patient, a 47 years old female, was not able to afford a more comprehensive treatment plan. Her budget was limited. She chooses the "Winged Pontic" option rather than the "flipper."

In photo 1 a missing lateral incisor, tooth \#7 is seen. The prefabricated "Winged Pontic" is seen in photo 2.

Photo 3 shows the prefab "Winged Pontic" trimmed and adjusted into the space between the support teeth without attachment composite affixed. The line of placement is confirmed as the "Winged Pontic" is adjusted.

Photo 4 shows the "Winged Pontic" lateral incisor \#7 with attachment composite applied to the proximal surfaces ready for insertion between \#6 and \#8, but only after preparation.

After treating the enamel of support teeth \#6 and \#8 with etchant, water cleaning and drying, clear resin and attachment composite are applied to proximal surfaces seen in Photo 5.

The prefab "Winged Pontic" (Photo 4 ) has first been etched for 30 seconds, cleaned with water, next treated with the $C B^{\circledR}$ "WP" Bond Enhancer, clear resin is applied, followed by attachment composite application to proximal surfaces as seen in Photo 4. The pontic is now ready for insertion between the support teeth.

The prefabricated, pretreated "Winged Pontic" is carried to the space and inserted as seen Photos 6 and 7 in the predetermined line of draw. The attachment composite is smoothed over all aspects of the pontic and support teeth and then light cured.

The "Winged Pontic" is layered over with the practitioner's choice of finishing composite. This is a time when creative artistic skills may be applied. Once cured, the occlusion is checked and adjusted in all excursions. Various flame shaped finishing diamonds are used for characterization. Final polish may be done with fine finishing diamonds 25 micron and 50 micron, and rubber wheels.

Final results are demonstrated in Photos 8 and 9.

\section{A New Persepctive}

This process, the Carlson Bridge ${ }^{\circledR}$ "Winged Pontic" tooth replacement system may open doors to new possibilities in the way dentists practice. Bio-synthetic tissue engineering ${ }^{(11)}$ is the leading edge in dentistry today.
This modern system of tooth replacement may also be a pleasant experience for the patient who can shorten his or her time in the dental chair and come away with an immediate dental cosmetic enhancement. Additionally, it will not create a financial burden or, require extensive healing time or unnecessary oral discomfort. The average cost of a traditional three tooth fixed bridge in Honolulu, after having two teeth reduced to pencil pegs, is about $\$ 4,400.00$. Our case study patient was charged \$2, 100.00 and was more than happy with that. In this day and age of limited dental health budgets, it is an idea whose time has come.

It is also beneficial to the dental practitioner since the procedure is shorter in duration, therefore physically less demanding, less complicated in that intricate tooth preparations are unnecessary, and ultimately more rewarding creatively, artistically and remuneratively.

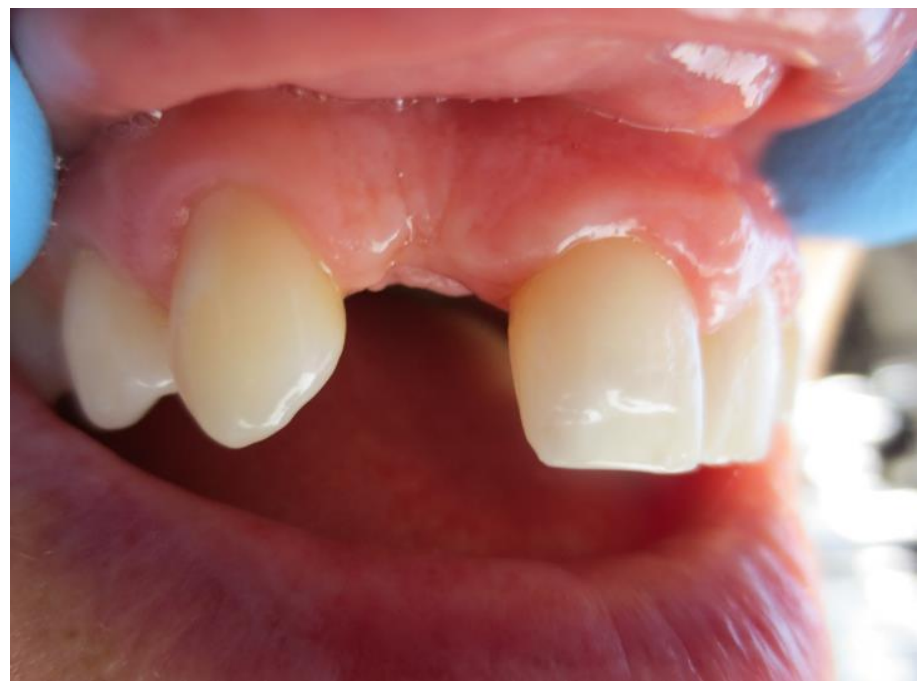

Figure1: Missing lateral incisor \#7 was due to a failed root canal. Both central incisior and cuspid were untouched and in good health.

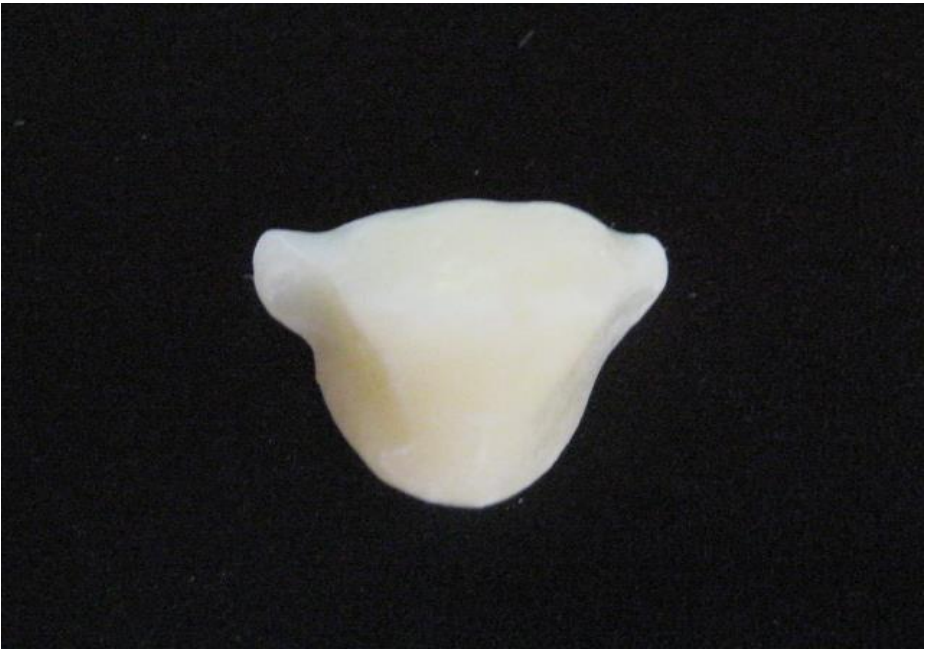

Figure 2: Prefabricated incisor composite, "Winged Pontic," facial aspect before adjustment. 


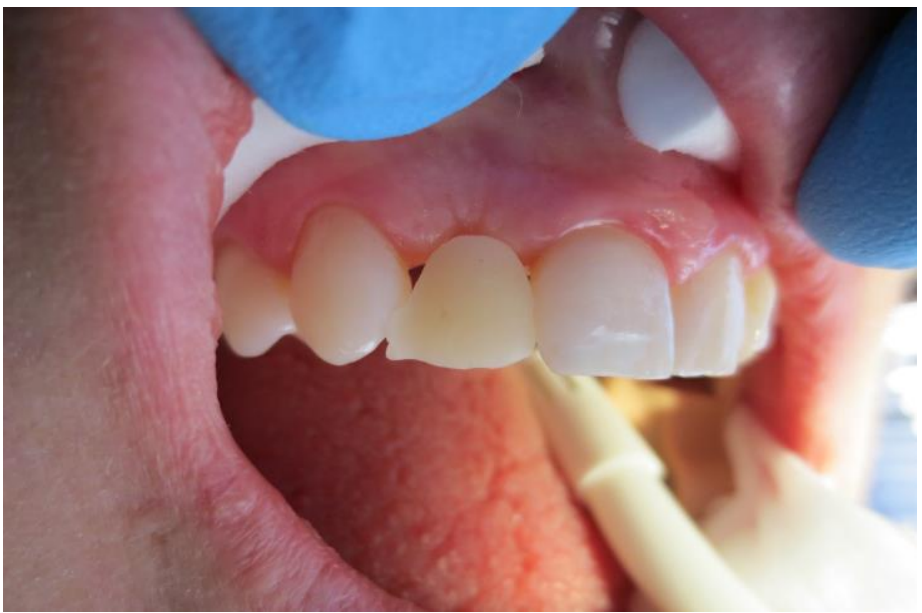

Figure 3: Adjusted "Winged Pontic" passively set into the edentulous space prior to the attachment phase, thus ensuring proper positioning and fit.

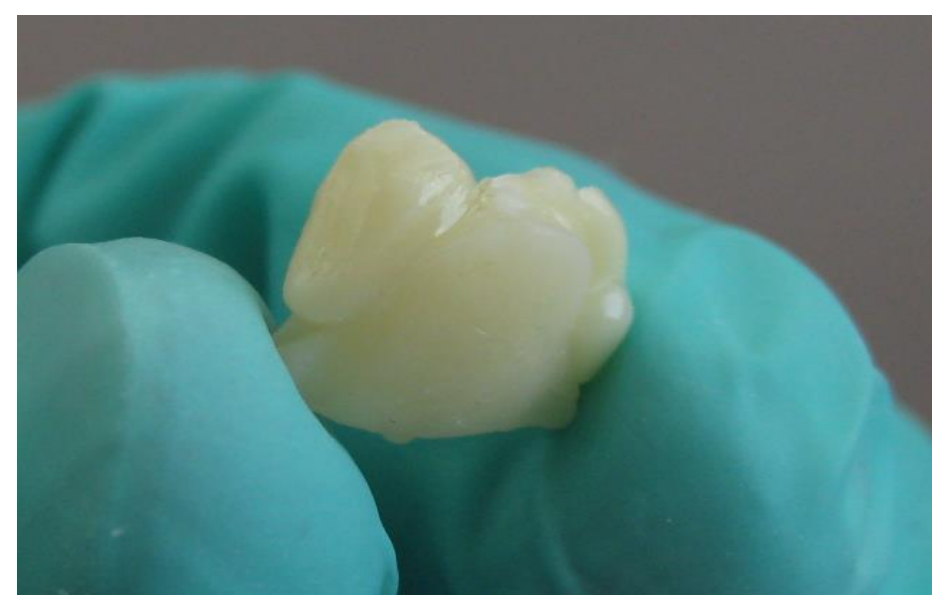

Figure 4: "Winged Pontic" with soft attachment composite on proximal surfaces, after the addition of CB-Silane and resin to the "Winged Pontic" body.

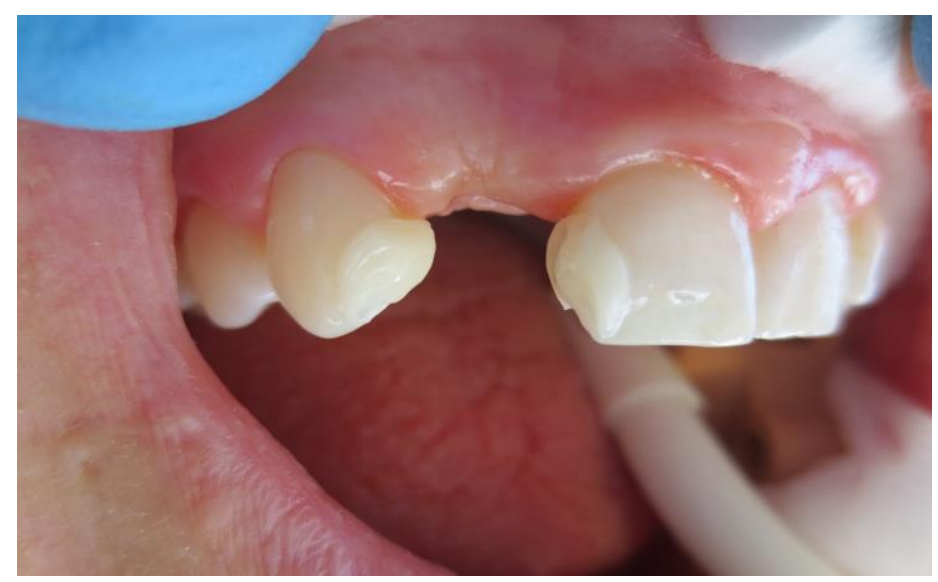

Figure 5: After etching and cleaning the support teeth surfaces, the soft attachment composite is applied for the attachment phase.

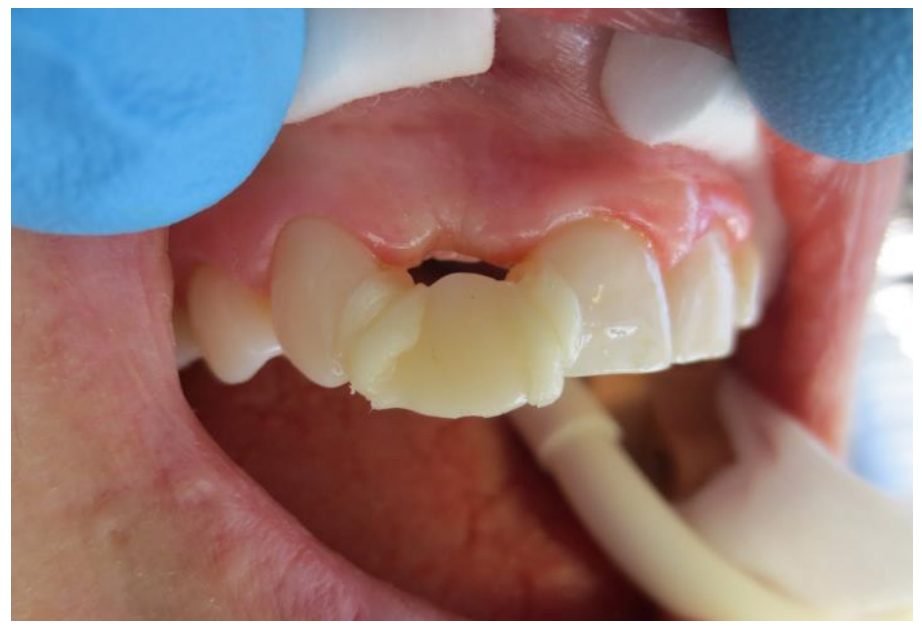

Figure 6: At the attachment phase, the "Winged Pontic" is gingerly inserted into the space according to its previously determined line of draw.

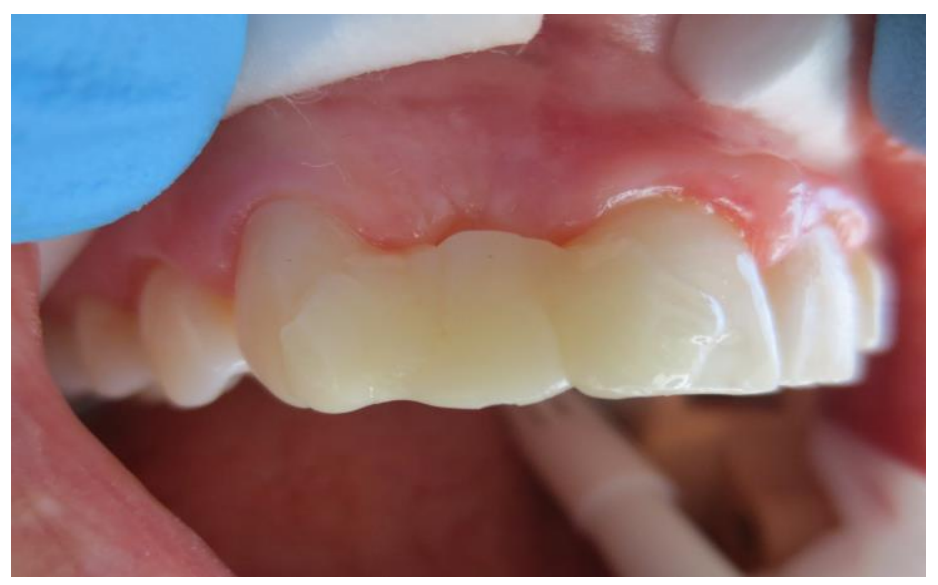

Figure 7: Soft composite is gently layered over the "Winged Pontic," both the facial and lingual aspects of support teeth, and photo cured.

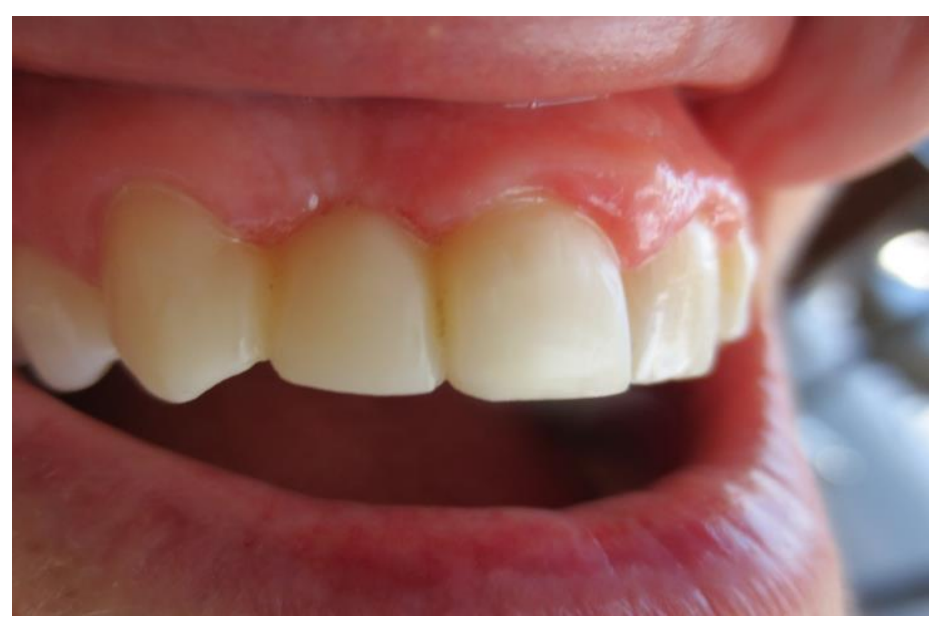

Figure 8: Preliminary sculpting is accomplished with medium to fine flame diamonds and rubber wheels after the occlusion is adjusted. 


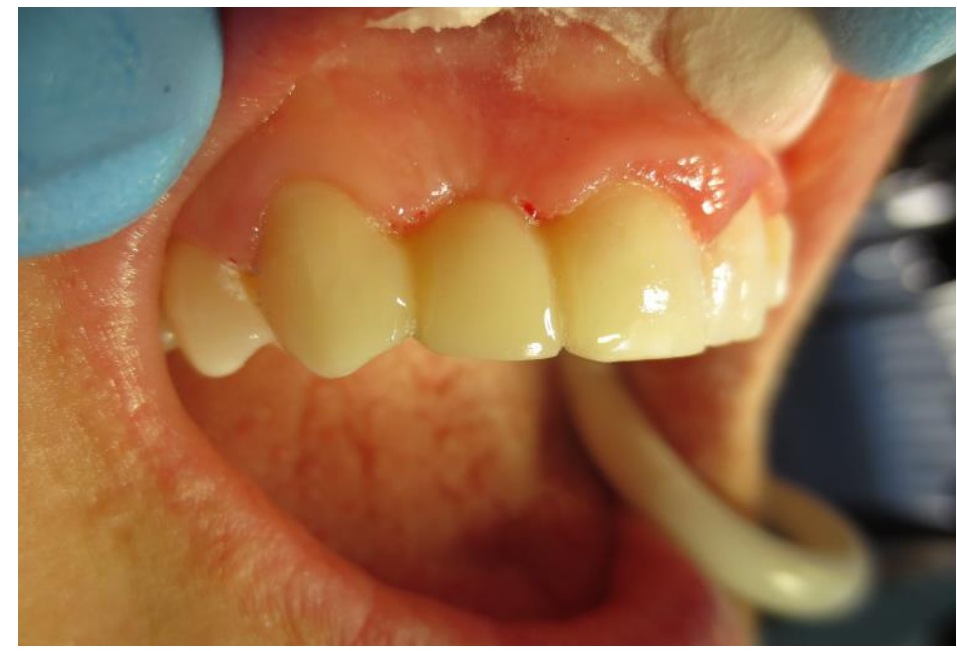

Figure 9: Final restoration after addition of high gloss finishing composite and polishing.

\section{References}

1. Christensen GJ. Fixed Prosthodontics, Avoiding Pulp Death. Clinical Research Associates Newsletter. 1995;19:1.

2. Christianson, G., How to kill a tooth. J Am Dent Assoc. 2005;136:1711-1713.
3. Jokstad A, Gokce M, Hjortsjo C. A systematic review of the scientific documentation of fixed partial dentures made from fiber-reinforced polymer to replace missing teeth. Int J Prosthodont. 2005;18:489-496.

4. Carlson, RS, D.D.S., "Breakthrough Dental Bridgework: The Bio-Logical Dental Bridge," Dentistry Today, 1999, Volume 18 , No. 1, pages 88-93.

5. Carlson, Ronald S., D.D.S., "Dental Artistry," General Dentistry, The Peer-Reviewed Journal of the Academy of General Dentistry, July-August 2003; Vol. 51, No. 4.

6. Carlson, RS, D.D.S., Cap it? Or Wrap it? Dentistry Today. 2009; Volume 28, No. 6, pages 74-75.

7. Belvedere, P., D.D.S., Turner, W. E., D.M.D., "Direct FiberReinforcement Composite Bridges" Dentistry Today, Volume 21, No. 6, page 88-94.

8. Knight JS, Whittaker DA. A new look at chair-side fiber reinforcement of resin composite. Gen Dent. 2003; 51:334-336.

9. Carlson RS. Immediate Post-Extraction In Situ Direct Lamination Composite Bridge. Dent Today. 2006;25:116-119.

10. van Heumen CC, Kreulen CM, Bronkhorst EM, Lesaffre E, Creugers NH. Fiber-reinforced dental composites in beam testing. Dent Mater., 2008 Nov;24(11):1435-43. Epub 2008 Aug 9.

11. Bayne SC, Ph.D., Dental Biomaterials: Where are We and Where Are We Going? J. Dent Ed., May 2005; Vol. 69 no. 5, 571-585.
This work is licensed under Creative Commons Attribution 4.0 License

To Submit Your Article Click Here: Submit Manuscript

DOI: $10.31579 / 2690-1919 / 081$
Ready to submit your research? Choose Auctores and benefit from:

* fast, convenient online submission

* rigorous peer review by experienced research in your field

* rapid publication on acceptance

* authors retain copyrights

* unique DOI for all articles

* immediate, unrestricted online access

At Auctores, research is always in progress.

Learn more www.auctoresonline.org/journals/journal-of-clinical-researchand-reports 